\title{
The Image of the Lyrical Hero \\ in D. Shostakovich's Symphony No. 4 \\ in the Light of the Ideas of Christian Anthropology
}

\author{
Natalia M. Naiko* \\ Krasnoyarsk State Institute of Arts \\ 22 Lenin Str., Krasnoyarsk, 660049, Russia
}

Received 15.01.2017, received in revised form 20.07.2017, accepted 28.07.2017

The hero of Shostakovich's Symphony No. 4, one of the most tragic and vividly expressive works of art, is a sort of the author's artistic counterpart. In his music with certain intonation means the composer models a personality with universal and individual, unique personal traits inherent to the composer. Application of concepts of Christian anthropology makes it possible to understand human nature, embodied in the image of the lyrical hero in Shostakovich's Symphony No. 4. The results of the intonational analysis lead to the conclusion that the intuitions of the human's divine origin and his spiritual nature constitute the conceptual core of few and brief lyrical episodes in the symphony. However, the main strengths of the lyrical hero's soul are distorted and weakened, and this nonintegrity makes him vulnerable to a hostile world. Implementation of these ideas determines a number of dramatic and compositional peculiarities of Symphony No. 4. Thus, music themes, characterizing the hero, have a single intonational "core", the permanent character of which symbolizes the existence of an indestructible core in the lyrical hero's soul and impossibility of his spiritual death.

Keywords: D. Shostakovich's Symphony No. 4, lyrical hero in music.

DOI: 10.17516/1997-1370-0128.

Research area: culturology, art criticism.

The concept of the "lyrical hero", which appeared as a philological term almost a century ago thanks to Iu. Tynianov (Tynianov, 1993: 224-229), still has not become a common term with a conventional meaning. The experts consider the reason for this to be the term's extremely broad application when any of the "lyrical I" is defined as the "lyrical hero" (Guseva, 2007). In musicology, the concept of the "lyrical hero" is used precisely in this vein. It is found primarily in V.V. Medushevskii's works (Medushevskii, 1993: 60-61) and is intended to reveal the features of the romantic composers' artistic world organization, to identify the peculiarities of a special type of musical tone that embodies the human's emotional world most directly - "from the first person" - and is psychologically subtle. In the context of classification of intonations suggested by V.V. Medushevskii, the extended interpretation of the concept of the "lyrical hero" is justified and appropriate.

(c) Siberian Federal University. All rights reserved

* Corresponding author E-mail address: mikinai@ya.ru 
Thus, the content of the literary concept is far from being exhausted; its clarification and disclosure of the meaning potential can be promising for some musical phenomena. The lyrical hero is considered to be one of the methods to reflect the author's consciousness in the text. The lyrical hero is called the authorpoet's artistic counterpart emerging from the text of lyrical compositions as "a clearly defined figure or life role, a person endowed with the certainty of individual destiny, psychological distinctness of the inner world" (Literaturnaia entsiklopediia..., 2001: 452). According to B.O. Korman, the lyrical hero is "both the media of speech and the subject of portrayal". Internal, ideological and psychological unity is typical for his appearance as different poems reveal a single human personality in his relation to the world and himself (Korman, 1972: 56-57).

Due to the fact that the author's selfsentiment ${ }^{1}$ is reconstructed in the lyrical hero, his image is accompanied with sincerity, introspection, confessional nature. However, the lyrical hero is "a unity of a personality standing behind the text as well as endowed with a characteristic feature of the plot" (Ginzburg, 1997: 155). So, the lyrical hero's appearance and fate also correspond to the author's attitude to the world and self-sentiment.

In this sense the concept of the "lyrical hero" in relation to the composer's opuses was not developed. This can be explained by a high degree of generality and well-known abstractness of musical expression, especially in the sphere of the purely instrumental music pieces as well as a desire to avoid direct, vulgar interpretations. At the same time, it seems that in certain cases its application is not only justified, but can reveal important content and conceptual layers of individual music pieces and an author's artistic world, in general.
The object of the research in the present paper is the lyrical hero in Shostakovich's Symphony No. 4, referred to, in accordance with the foregoing, as a way of reflecting the author's consciousness in the text, the author's artistic counterpart, the unity of a personality behind the text, who manifests himself through the attitude to the world, reflection (including self-reflection) and is endowed with a characteristic feature of the plot. Thus, the lyrical hero in music may find himself not only through modeling of attitudes, feelings, emotional reactions, but also through other phenomena of consciousness. It is a human personality that becomes a core contributing to the diversity of human manifestations and, at the same time, a centre uniting it.

Symphony No. 4 that was composed by Shostakovich at the age of 28-29 is known as one of the most vividly expressive and tragic of his works. G.D. Glikman, a painter and sculptor with a professional - and particularly "tenacious" visual memory, left not only numerous images of the composer, but also a verbal portrait of young Shostakovich. Noting his unusual, delicate, "feminine" beauty, the harmony of the external appearance, permeated with "the dazzling light of genius" (Glikman, 2008), the memoirist considered these traits to be a true reflection of Shostakovich's music. The photos of the 2030 -ies captured the composer's image which is precisely this - a slim figure, a delicate face, a clear and sharp glance.

Reflecting on a "challenging but very organic link between a human's character and his appearance, the composer's appearance and his music", Glikman made a point, regarding Shostakovich, the point being that "his personality and music are most accurately expressed in his young face, on which the life imposed its heavy print later..." (Glikman, 2008).

Through all his restraint, even withdrawal (probably, increasing with age), young 
Shostakovich appeared before a narrow circle of friends and relatives as a bright all-arounder. On the one hand, he exposed himself as an artistic personality with an extraordinary sense of humor and propensity to drawing, a temperamental, passionate and even risky man (Perepiska Dmitriia Shostakovicha..., 2006). On the other hand, Shostakovich is known for his modesty, amazing tactfulness, tolerance and patience towards other people. These traits combined with his inner stamina in his views. Shostakovich avoided disputes. According to G. Glikman, they tired him out and disturbed his inner life. But if a dispute related to something fundamentally important for Shostakovich and a companion impressed him, "he could be very persuasive and could aggressively and passionately defend his point of view" (Glikman, 2008).

Unusually keen emotionality, even passion, depth of feelings, tenderness and subtle responsiveness coexisted with stupendous internal discipline (Glikman, 2008) and self-control. In many cases people around Shostakovich could only speculate on his shocks, despairs, fears, worries, and disappointments, while imaging certain circumstances of his life on themselves. Rare friends were informed about similar experiences. He did it stingily, as if detached and often with irony.

It is obvious that, in general, the composer's inner world was hidden from an outside observer. Yet, some of its parts found their artistic representation in his music. This is to a high degree true for Symphony No. 4. The work on it lasted from 13.09.1935 to 20.05.1936. According to S.M. Khentova (Khentova, 1985: 422), by the end of 1935 the first part was completed and the most of the second part was written. Shostakovich was captured by the idea of creating a symphony of a new type and sought to make an expression psychological and emotionally naked and combine it with tense drama, sharp contrasts, and grandeur of scales. On the one hand, the biographers note that the young composer's creative search is to a considerable degree connected with his comprehension of the principles of Mahler's symphonism. On the other hand, many of these traits have already become evident in the opera "Lady Macbeth of the Mtsensk District", which was performed in the Soviet Union and abroad for more than fifty times in the course of two years. Reflecting on the influence of Mahler's music on Shostakovich's Symphony No. 4, it must be remembered that Shostakovich was 19 years old when he declared himself to be a creative, independent, autonomous artist with a brilliant compositional technique. Over the next decade his professional experience widened and deepened. This led to solving of a variety of creative tasks. Obviously, Mahler's music played a role of a sort of mirror and made it possible to feel and bring the so far undeveloped powers of a soul and deep intentions outside, that is to give them form and substance.

Therefore, it is difficult to say how the events in the beginning of $1936^{2}$, which opened the campaign for the persecution of Shostakovich, affected the composition of the symphony, and whether its conception underwent significant changes. It is known that the composer, who did not participate in the discussion, compiled an album of scissorings from the Soviet press with reproaches and accusations against him, as well as a negative evaluation of his works. His condition was anybody's guess. According to V.G. Dulova's reminiscences, "D.D. was very upset, and so were we, his friends and admirers". In Leningrad it was said that "Shostakovich always has cyanide of potassium with him" (Perepiska Dmitriia Shostakovicha..., 2006). Responding to V. Dulova's concerned letter, Shostakovich wrote: "The rumors about cyanide of potassium are $100 \%$ exaggerated. All this talk is nonsense and stupidity. I will live to rejoice and 
grieve till I die a natural death. But I will never and in no way resort to violence over myself. To tell the truth, I do not live very well now. I have been trying to understand what is happening now. And I fail to understand much. My brain cannot take such a huge load. $<\ldots>$ It is difficult to survive the destruction of all my work now as I've never worked thoughtlessly, or carelessly. There is a drop of my fresh blood in my every note. $<\ldots>>$ Till now I've lived the following way: eating, drinking, sleeping, doing something and composing music. Right now burning and painful thoughts are added to all listed above" (Perepiska Dmitriia Shostakovicha..., 2006).

Thus, at the age of 29 Dmitri Shostakovich had to go through a painful, bitter experience of denying the values of his creative aspirations and ideas. The scope and aggression of this denial was truly monstrous. For a person with a talent of this magnitude, such a derogatory suppressing of a deep need of self-actualization is tantamount to an attempt on the personality's hidden content, innermost personal meanings.

It is striking that in the first part of Symphony No. 4 in the conventional artistic form the situation of a human's confrontation to the extremely hostile world was captured before it found its manifestation in real life. The music anticipated the subsequent events. "It is the composer himself who primarily became a hero of the symphony" (Khentova, 1985: 432). The relations of a human and external reality are antagonistic in the artistic space of the symphony: the world of masks, which is as colorful as carnival and, at the same time, emasculated, presses a personality, invades the innermost depths of his soul, and seeks to destroy it.

The lyrical hero of Shostakovich's Symphony No. 4 is an artistic model of a personality who has both human traits (an ability to reflect, evaluate, act and, thus, flexibly respond to current events) and individual character. A special spiritual fragility, psychological subtlety, and acuteness of world perception are inherent in him. They cause insecurity and vulnerability - all those traits that are inherent in the personality of the composer himself.

Relative to the outside world, the lyrical hero of Symphony No. 4 exists in some other dimension, in his own one. The moments of shift to the lyrical hero's intonational sphere is usually accompanied with a significant slowing of tempo and rhythm, indicating a different temporal organization of the inner space. The time of the outside world, which is relentlessly pushing, is sort of moving away. Its course calms down and pauses. "The internal time" is apparently psychological: it is the time of emotions, thoughts, introspection; it is, to some extent, something independent from external actions.

The hero is as though in a different, autonomous space. This space is the space of his unique "I", that, if compared with everything around, is perceived as something small against the background of the overwhelming, big. This feeling is created mainly by texture solutions: the lyrical hero is separated from the mass; his voice has its own individual timbre. The simultaneous deployment of several melodic lines in the sphere of the lyrical hero becomes a reflection of a human's multi-sidedness, a polylogue of inner voices of his soul. The spheres of the world and the lyrical hero are contrasted through the opposition of tutti and solo: tutti is some aggressive undifferentiated mass, whereas solo is something individual, endowed with unique intonation.

Chamber sound, special transparency of texture, intonational differentiation of melody lines, narrow range, slow tempo, and muted dynamics enrich the "monologue" sections with deeply personal, confessional nature. An important role is played here by a dynamic contrast which also becomes a reflection of the 
antithesis of mass and individual. In contrast to the roaring of the world, the personality's space is immersed in silence. The silence creates a sense of depth, perspective, and infinity of the lyrical hero's inner space that he probably does not fully realize. This deep, ineffable infinity has a sort of freedom from the straightforward, superficial, limited and finite outside world. It also contains a condition for anticipation of the secret of his unearthly origin.

Timbre solution of the monologues in the lyrical sphere is indicative: as a rule, these are solo wooden or string instruments, long, vibrating tone of which flexibly reproduces myriads of shades of a human's speaking and singing voice. The use of the middle register is also symbolic.

The melodic nature of the thematic structure is of great value for the intonational realization of the sphere of the lyrical hero. The melody is "a living voice of the heart", "enunciation of a human" (Medushevskii, 1993: 89), that is perceived as a coherent statement of not many people, but of one "author" only. Thus, it is possible to speak about the individualization approach through the melodic beginning.

As noted above, a human and his world in the artistic space of Shostakovich's symphony are polarized, the reality, which is contemporary for the composer, being interpreted through the image of the world. Devaluation of human personality became a "disease" of the XX century with its monstrous "complications" in the form of wars, terrorism, totalitarianism, invention of increasingly sophisticated means of enslavement and destruction ${ }^{3}$. The composer sensitively reacts to these terrible symptoms, showing a true state of things in his music. That is why the faceless mass is that "primary element", that "substance" which the objects of the simulated world are "molded" from. And with all the diversity of their external forms, the nature, revealed and exposed by the composer, remains the same, the nature being aggressive impersonality.

The world space, primarily modeled by texture means, is sort of overcrowded in Symphony No. 4: a chaotic pile of timbres ${ }^{4}$ brings the idea of a senseless bustle into reality. To embody the world commotion the composer often resorts to polyphonization of music texture when a combination of independently moving layers generates almost a sonorant effect. Rumble, hum of some overwhelming mass conditionally displays disharmony of the world and evokes an aesthetic reaction of disapproval, rejection. This, in turn, leads to the ethical assessment of a phenomenon artistically depicted in the music as a terrible, threatening destruction. The concepts of the "world" and the "evil" in Shostakovich's symphony seem to merge together: everything external, which surrounds a person, is evil.

The idea of a relentless offensive in the melodic pattern is embodied with the simplest rhythm and intonation formulae, generally based on a straight ascending or descending conjunct movement. There often appear kinds of modal "mutations": fragments of whole- and half-tone scales with the semantics of the impersonal and lifeless they imply in the present context due to their symmetry, the tendency of dominance of the rhythmic beginning over the melodic one being manifested in the intonational sphere of the evil. It is not by chance that the composer chooses motor genres: rhythmic uniformity and regularity, manifested in various aspects, emphasize the primacy of mechanistic origin.

The world, in which the evil reigns undividedly, is embodied in the symphony not only through the "onslaught" themes. The evil is insidious, it hides its true nature behind various masks, and then the reality becomes similar to an endless, senseless carnival with endless flashes of evil grimaces that is embodied in a kind of dance suites in the first part and the finale. As 
for the world, it reveals its downside to a human: the ordinary suddenly reveals the terrible. Accumulation of a faceless mass, or, in I.A. Il'in's words, of "the world dust" as rootless particles that have fallen from the coherent order of being and do not know the meaning and purpose (Il'in 1994: 270-271), turns life into a nightmare: shallowness, stupidity, primitivism, bad taste, vulgarity are as if absolutized in outer space and cramp a personality from all sides.

Rejecting the external world and the evil that reigns in it, the lyrical hero of the symphony intuitively feels a fear of death and chooses a path different from that of evil. What gives him a reason for such a choice? What gives him strength to make that choice and follow it? What gives a personality the right to confront the world? What does the lyrical hero protect from the offences of the world? What secret does he keep to himself? Here we face a central anthropological - question: what is the nature of a human embodied in the image of the lyrical hero? It entails a methodological question: what approach to the human personality, captured in the music by Shostakovich, can cover it as fully as possible?

The problem of a human is thought over in B.P. Vysheslavtsev's works "Etika preobrazhonnogo Erosa" ("Ethics of the Transformed Eros") and "Vechnoe v russkoi filosofii" ("The Eternal in Russian Philosophy") (Vysheslavtsev, 1994). He generates the evidences from the European science of several centuries old, including Z. Freud's and K. Jung's contemporary surveys, refers to the materials of the Upanishads, Vedanta, Buddhism, Christian asceticism, treating the latter as one of the greatest and most authoritative sources.

In a series of publications of the last decade S.S. Khoruzhii, a modern Russian philosopher, draws our attention to the fact that an integral and profound doctrine of a human was developed in the spiritual practice of Orthodox asceticism. Moreover, the researcher is convinced that although the anthropological discoveries of Orthodox monasticism root in a particular era and a specific environment, they are not inherently limited by their time and environment (Khoruzhii, 2005).

Formore than two decades V.V. Medushevskii had been speaking about the need to apply the concepts of Christian anthropology to the analysis of music. Basing on its foundations, he makes a significant contribution to the development of the theory of musical intonation, writes a book "Dukhovnyi analiz muzyki" ("The Spiritual Analysis of Music"), outlines a path of the spiritual music psychology formation.

What is a human from the point of view of the patristic teaching? He is the crown of creation, the abode of Divine qualities, and the possessor of an immortal soul which is the bearer of the image of God. "The laws of virtues: prudence, knowledge, wisdom, faith, love, and directing mind" were put in his being in the course of creating his soul (Zhuravskii, 1995: 86). This is because the human soul is called an "intelligent being", an "inner man". For God it is more valuable than all the creatures: according to St. Augustine, "only God is better than the soul $<\ldots>$, the angel is equal to it, and the rest of the universe is below it" (Vysheslavtsev, 1994: 129). According to the original purpose a human had to dwell in the World of the Glory of God (Zhuravskii, 1995: 113).

Referring to Rev. Macarius the Great, Ignatius Brianchaninov writes about a human's original nature: "Before the fall of man his body was immortal, alien to diseases, alien to his $<$... real gravity, alien to sinful and carnal sensations that are natural to him now $<\ldots>$ His sensations were much thinner, their effect was much more extensive, $<\ldots>$ a man was capable of sensual vision of the spirits, the category 
of which he belonged to by his soul, he was capable to communicate with them, capable to the knowledge of God and communion with God, which were akin to the Holy spirits. $<\ldots>$ A man, clothed in a body, was able to dwell in the heavens" (Rouz, 1995: 68).

The fall changed both the human soul and the human body. The body fell under the influence of the material world, entered the category of the animal bodies (Rouz, 1995: 69, 70). Since then, according to Archpriest Ioann Zhuravskii, immaterial intelligent soul became unreasonable: it became material, real; it is in thoughts and feelings of the flesh (Zhuravskii, 1995: 51). The qualities of the soul change - the mind loses an ability to judge, distinguish between good and evil, cognize spiritual structure, apprehend the divine will (Zhuravskii, 1995: 64), the attention becomes illegible to thoughts, desires and feelings, allowing the ill mind to wander, rush in a whirlwind of harmful dreams, the will becomes flabby and weak, the heart gets cold and bitter, passionately lives in carnal lusts without noticing the way they drain the spiritual energy of the soul, the memory is no longer held by constant mindfulness of God, forgetting its prototype. In this state of the soul the heavenly life became unavailable for a human.

However, the gift of Grace "is not exterminated in us by our sins, it is only buried as some treasure in the land of our every passion" (Zhuravskii, 1995: 52). Like an icon, a human keeps the image of God in him. It is no coincidence that Zhuravskii writes that we are "spirits, but covered with a rough "skin" - the physicality, and our nature is "not in the 'skin' but in our invisible intelligent nature" (Zhuravskii, 1995: 126).

On the basis of the intonational analysis it can be concluded that the intuitions of the human's divine origin, his spiritual nature constitute the conceptual core of few and brief lyrical episodes of the symphony 5 .
Expressiveness of the lyrical themes of Symphony No. 4 is determined by the alloy of psychologically multifaceted expressive speech intonation and rhythm of the melodic idioms of the Russian song styles (especially the lyrical plangent songs). The first "layer" embodies personality in the aspect of unique individuality (hence, there is a subtle psychological differentiation of intonations, chromaticism, and rhythmic flexibility). The second "layer" points to the "roots", the "roots" being national and spiritual genesis of the lyrical hero. The song genre basis, modal organization, and variant development determine the "core" of the lyrical themes. It is the intervals of fourths and fifths that give them their objectified nature and embody the idea of pristine purity.

Lyrical monologue themes become a quiet reminder of the Homeland ("it is not only the country where we first tasted the sweetness of being, it is far greater and higher, it is a country where we could see the sky" (Bulgakov, 1997: 7)) and genesis. They recreate the process of introspection, approaching to that "inner nature" which kept the memory of the good, and a man as the crown of creation and of what man he should be according to the original plan. Thus, his own depth, ineffable infinity open to the lyrical hero in the silence of concentrated thinking. It is something higher, mysterious, and innermost in the soul and makes its center. The patristic literature uses the symbol of "heart" to refer to this mysterious depth which is available to God only.

B. Vysheslavtsev writes that "the Bible ascribes all the functions of consciousness to the heart" (Vysheslavtsev, 1994: 272): it feels, thinks, makes decisions, contains such a hidden intimate function as the conscience. The "heart" means a certain hidden center, some depth inaccessible to the eye. It is something more incomprehensible, impenetrable and mysterious than the soul, it 
contains the criteria for the verity, truth, and values perceived by it directly, for their being is ideal. To get closer to understanding of his own nature a human must certainly feel a sense of awe towards the bottomlessness of his heart and see, according to Leibnitz, "the entire world, full of infinity" in himself (Vysheslavtsev, 1994: 273), this world being "a man hidden in the heart" (Vysheslavtsev, 1994: 275).

The lyrical hero intuitively feels this depth in himself, at least as the opposite of "superficiality" of the world. It is immersion in the infinity of his own heart that gives him an opportunity to behold the ultimate reality and hear the voice of Eternity. If we take into account the fact that God reveals himself only to those who can feel Him, appealing to the similar, then the revelations of Eternity themselves (symbolically captured in several brief scenes in the $1^{\text {st }}$ and $3^{\text {rd }}$ parts of the symphony) already indicate the existence of a certain innermost centre in the personality. However, the lyrical hero does not regard it as a purpose of introspection, a point of an expected meeting with God. Feeling something definitely valuable in himself, the lyrical hero desperately defends himself from the attacks of the outside world. Yet, he does not know exactly what he defends as he finds God in the soul. And this nonintegrity makes him vulnerable to the world.

The concept of 'heart' is often identified with the concept of 'spirit'. "A man is constituted by three measures, three natures: physical - the mouth, intelligent - the mind and spiritual - the spirit or the heart" (Vysheslavtsev, 1994: 184), the soul is deservedly above the body, it "animates" the body; the spirit is above the body and soul, it "spiritualizes" the body and soul (Vysheslavtsev, 1994: 283). In Shostakovich's symphony the theme of the Russian Songs, that sounds before the coda of Part III and most fully exhibits the idea of the genesis, becomes a symbol of this personality's spirituality, non-disturbance of the hierarchy of his "natures". This "flowing" melody of the strings in the middle register, which is thoughtful and sad and, at the same time, filled with loving kindness, seems to have absorbed not only the endless vastness of the Russian land, but also the bottomless sky, the Higher Love and Wisdom.

However, the lyrical hero of the symphony is Shostakovich's contemporary, a man who has lost faith and has been living without God for, probably, several generations. According to father Ioann Zhuravskii, he is "that prodigal son who left a sweet Communion inherent in him, went to a far-away foreign country and wasted his spiritual property" (Zhuravskii, 1995: 174) and became an easy prey for the forces of evil. V. Medushevsky also writes that just as "an icon with the blasphemous words on it turns into a desecrated icon but never a simple board, a man, no matter how low he fell, will never be 'a piece of thinking matter" (Medushevskii, 1994: 53) and always keep the image of God in himself.

The features of the image of God could be discerned in the lyrical hero. Although all of them are distorted and weakened, as a personality he, nevertheless, has a number of traits that still allow him "to be above the rest of the universe" according to the original plan.

Talking about the traits of a personality, the Fathers of the Eastern Church focus on his/ her "intelligent nature". The mind is a gift of differentiation and judgment (Vysheslavtsev, 1994: 287) that makes a man godlike. God distinguishes lies from truth and good from evil and judges them fairly. He endowed a man with the same ability. The lyrical hero of Shostakovich's symphony has this gift: he discerns and rejects the evil that reigns in the world; he fiercely resists the intrusion of the evil in his inner space. This is also evidenced by the texture opposition of the lyrical hero's intonational sphere and the sphere of the world and the musical material depicting 
the personality's different reactions to the evil: despair, protest, anguish, and suffering.

Another important trait of the personality, according to the Holy Fathers, is attention, which is an ability to select the content of the external world and let it inside. In patristic literature attention is called "trezvlenie" ("sobriety") Sobriety "prevents the "enemies" from getting inside the heart, blocks the entrance there..." "The pure heart of him who gets certain in sobriety $<\ldots>$ becomes a reservoir for the non-imbeddable God" (Philotheos of Sinai (Vysheslavtsev, 1994, p. 72)). Sobriety "takes us out of a dying, earthly, mortal being <...> into a New eternal, heavenly immortal being" (Zhuravskii, 1995: 4647). However, Shostakovich's Symphony No. 4 captures the reverse processes. The lyrical hero's attention is weakened, it not only removes him from the earthly world, but also makes it possible for the forces of evil to invade his inner space, distort and vulgarize his innermost contents. Attention is so weak that the personality does not refer to the Ultimate Reality even at the moments of its manifestations embodied with a particular set of intonational means?

In addition, the lyrical hero quickly "forgets" the moments of insights and is vulnerable to the aggression of the world, as he is ignorant of the memory of $\mathrm{God}^{8}$ which is the only available means of protection from the effects of evil. It is in the lyrical hero's imaginative sphere where we find the moments of "remembering", detection of a deep connection with national roots and spiritual foundations. Yet, each time the voice of memory is silenced by the influence of the external world (the lyrical "soaring" themes are invariably accompanied with the intrusion of a thematic sphere of evil). At the same time, it is this deep mindfulness that becomes a prerequisite for the rejection of the evil of the world by the lyrical hero. Recognizing it and relating its manifestations (even unconsciously) with a certain moral standard, stored in the deepest layers of memory, the personality does not accept it, and this rejection causes the personality's deep suffering.

There is no love in the world surrounding the personality. According to the Apostle Paul, "love suffers long and is kind, $<\ldots>$ does not envy $<\ldots>$ does not parade itself, is not puffed up, does not behave rudely, does not seek its own, is not provoked, thinks no evil, does not rejoice in iniquity, but rejoices in the truth; bears all things, believes all things, hopes all things, endures all things" (1 Corinthians 13: 4-7). And where there is no love, according to Gregory of Nyssa, "all the features of the image of God are distorted" because "God is love and man is love" (Vysheslavtsev, 1994: 289). Yet, the "lamp of love" almost went out in the lyrical hero's soul. He is unable to see the "robe of God" in every living thing; he does not distinguish individuality in anything and anyone from the surrounding space: everything is merged into faceless aggressive mass. This determines a sort of dispersion of the themesimages of good (they seem random, are not developed or consolidated) and a huge imbalance in the relation of imaginative-and-intonational spheres of the world and the lyrical hero. Even "the symbol of the Russian Songs" theme, which all the dramatic line of the lyrical hero leads to and which embodies the idea of the image of God in a human, is not developed or claimed.

The lyrical hero's will as an active, free power of the soul (according to the Holy Fathers' definition) is also weakened. In the original sense the will is given to a man for him to put the will of God to life 9 . For the fallen man the will is a means of getting certain on the path of returning to God: according to I. Zhuravskii's thoughts, "intelligent will selects and approves its own eternity in the moment of time" (Zhuravskii, 1995: 192), leads a man to salvation from the busy, mortal, temporary world. Yet, for the hero of Symphony 
No. 4 it is only enough to divert his gaze from the external reality, try to get disconnected from a crazy whirling of the world, withdraw into his inner world. At the same time, he lacks the strength to consciously embark on the path of spiritual purification. At the intonational level, the idea of the lyrical hero's "weak will" is implemented in large-scale proportions of the sections representing the polar imaginative-andintonational spheres, as well as in the lack of development, non-fixedness of "soaring" themes, and their incompleteness. They seem to fade away, languish.

The personality's most important trait is freedom of choice, ability to accept and reject. Gregory of Nyssa speaks of freedom as of "an ability to decide and select from oneself, from one's own nature" (Vysheslavtsev, 1994: 287) ${ }^{10}$. A human's god-likeness is in freedom: according to St. Macarius the Egyptian, "no natural entity is free - neither the sun, nor the moon, nor the earth, nor the animals; but God is free and man is free" (Vysheslavtsev, 1994: 286).

Rejecting the outside world, the lyrical hero of Shostakovich's symphony unconsciously resists the aggravation of his fall. The burden of his position is that he does not know the way of spiritual ascent to God. The lack of faith makes the lyrical hero's position extremely unstable. Even at those moments when the Ultimate Reality reveals itself and the saving hand is as if stretched the lyrical hero is unable to take it since God does not attract to himself by force ${ }^{11}$. As the lyrical hero of Symphony No. 4 is not a believer, he deprives himself of true freedom since the "the great godlike freedom of man, the great value of personality, the great independence from everything that is hierarchically subordinate $<\ldots>$ is preserved only when he recognizes the dependence on the hierarchically superior, <..> on the "Almighty", on the Father" (Vysheslavtsev, 1994: 125). It is this high dependence that eliminates lower dependence and gives true freedom. The lyrical hero of Symphony No. 4 tends to be independent of the world, vaguely sensing some reason to this. However, he is unable to gain full freedom because he is not aware of his dependence on God, thus remaining in a state of half-freedom.

Comparing the Christian understanding of the personality and "the model" of the personality created by means of art in Shostakovich's symphony, we come to the conclusion that the composer brings to life the idea of the personality not only from the standpoint of individual subjective "I" but comprehends it on a philosophical level as a certain complex because, according to Vysheslavtsev, "a free personality, a "character" in history and personal biography is a special category: it is not only the awareness of aims and thinking of means $\langle$... $>$, it is primarily the knowledge of the system of values and the energy of will aiming at their

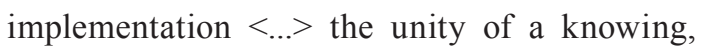
evaluating and acting subject" (Vysheslavtsev, 1994: 185).

Thus, the lyrical hero in Shostakovich's symphony becomes a sort of a generalized portrait of a contemporary, a non-integral human whose essential powers of the soul are distorted and weakened. A deep genetic "seed" - the image of God - does not "grow" in his soul, that is why he cannot know the reasons for this state of affairs and change something in himself and in the world. This results in an obvious doom to failure of all the personality's scattered attempts to withstand the onslaught of evil forces, desperation on the verge of collapse, and, ultimately, death ${ }^{12}$. A tragic predetermination of the lyrical hero's fate is caused by his unbelief.

However, despite the fact that the lyrical hero is unaware of his fundamental roots as the way of salvation from the evil, reigning in the world, as if he forgets about them, these are unchangeability 
and indestructibility of the intonation "core" of music themes, characterizing him, that symbolize an indestructible core in the lyrical hero's soul. And if the essence of the world in Symphony No. 4 is a spiritual death, then the fact that this personality's core is beyond the power of the world means (in this case) being beyond spiritual death. Thus, having embodied the lyrical hero's ultimate position on the border of existence, D. Shostakovich opens the ontological perspective of the problems of the personality and, perhaps, comes to the embodiment of the immortality of the human spirit in an unconscious form. Therein lies the uniqueness of the genius author's artistic insights, the relevance of which has not lost its sharpness nowadays.

\footnotetext{
It may have no coincidence with the way the real author is perceive by the others.

2 At the peak of glory of "Lady Macbeth" and on the eve of its premiere at the Bolshoi theatre the newspaper "Pravda" ("Truth") published the articles about Shostakovich's ballet "Svetlyi ruchei" ("The Bright Stream") (6.02), the articles being "Sumbur vmesto muzyki" ("A Mess Instead of Music") (28.01) and "Baletnaia fal'sh" ("The Ballet False"). They filthily and humiliatingly "criticized" Shostakovich's opera and ballet, stating a tough stance of the party leadership in relation to free art. The composers of different generations, professors of the conservatories, critics, musical and public figures took part in a large-scale "debate", initiated by the party bodies.

3 One of the manifestations of this "disease" nowadays is that a human turns out to be "not a person, having his/her independent value, but a commodity with its market price" (Rynkovskaia, 2015: 21).

4 The most essential elements of a characteristic feature of the image sphere of the world are assertive, oppressively heavy sound of brass instruments, often entering the low register as an entire group, and introduction of percussion instruments in the climactic zones. They expose the tutti noise nature.

5 In the first part it is a "false secondary" theme played by the $1^{\text {st }}$ and $2^{\text {nd }}$ violins in the octave doubling against the background of a chanted line of cellos (Fig. 7); the theme of the secondary part is a melody of the solo bassoon, supported by a stingy, "pointlike" accompaniment of cellos and double basses (Fig. 31); the same theme is for the violins in Des-dur (Fig. 84); the melody of the English horn (Fig. 96); a "false secondary" theme of the $1^{\text {st }}$ violins against the background of the rhythmic accompaniment of other strings (Fig. 101). In the finale it is a theme of Russian songs in the part of the $1^{\text {st }}$ violins (Fig. 230) and its motives - "the harbingers" (Fig. 227-229).

6 V. Medushevsky explains the meaning of this name by the fact that in the mundane everyday life we are like drunk men: we talk without hearing the truth, irrelevantly judge about everything. Sobriety (attention) also cures intoxication with madness, provides a man with an opportunity to see everything in its true light (Zhuravskii, 1995: 60).

For more details refer to: Naiko, N.M. (2012).

8 St. Gregory the Theologian instructed: "Remember the name of God more often than you breathe for it is more necessary to remember God than to breathe" (Zhuravskii, 1995: 89).

9 The Savior's words "My food is to do the will of him who sent me" (John.4:32) can serve an example of proper understanding of the will.

10 It is in freedom that diametrically opposed opportunities for a man lay in: having fallen once, he is free either to aggravate his fall and die for God or to be saved.

11 As is stated in the Book of Revelation (3:20), "Behold, I stand before the door and knock: and if anyone hears my voice, and opens the door, I will come in to him...".

12 For more details refer to: Naiko, N.M. (2012).
}

\section{References}

Bulgakov, S. (1991). Moia rodina [My Motherland]. Avtobiograficheskie zametki. [Autobiographic Notes]. Paris, 7-24.

Ginzburg, L.Ia. (1997). O lirike [On Lyrics]. Moscow, 409 p.

Glikman, G.D. (2008). "Shostakovich, kakim ia ego znal" ["Shostakovich as I Know Him"], In "Evropa ekspress" - bol'shaia russkoiazychnaia ezhenedel'naia gazeta Germanii [“Europe Express", a German Large Russian Language Weekly Newspaper], 38 (446), November 25.

Guseva, L.A. (2007). Liricheskii geroi N. Glazkova: iazykovye sredstva sozdaniia obraza: Avtoref. diss. ... kand. filol. nauk. [N. Glazkov's Lyrical Hero: the Language Means of Image Creation: Abstract of the PhD Thesis. Yaroslavl, 2007. Available at: www.dissercat. com/content/liricheskii-geroi-n-glazkova-yazykovye-sredstva-sozdaniya-obraza (accessed 15 February 2013). 
Il'in, I.A. (1994). Poiushchee serdtse. Kniga tikhikh sozertsanii [The Singing Heart. The Book of Quiet Contemplations]. Il'in, I.A. Sobranie sochinenii v 10 tt. T. 3. [Collected Works in 10 Volumes. Vol. 3]. Moscow, 227-380.

Khentova, S. (1985). Shostakovich. Zhizn' i tvorchestvo. T. 1 [Shostakovich. Life and Creative Work. Vol. 1]. Leningrad, 544 p.

Khoruzhii, S. (2005). Ocherki sinergiinoi antropologii [Sketches on Synergetic Anthropology]. Moscow, $407 \mathrm{p}$.

Korman, B.O. (1972). Izuchenie teksta khudozhestvennogo proizvedeniia [The Study of the Text of a Work of Art]. Moscow, $113 \mathrm{p}$.

Literaturnaia entsiklopediia terminov i poniatii [Literary Encyclopedia of Terms and Concepts] (2001). Moscow, NPK “Intelvak”, 1600 p.

Medushevskii, V.V. (1993). Intonatsionnaia forma muzyki [The Intonation Form of Music]. Moscow, 262 p.

Medushevskii, V.V. (1994). Mysli o pravoslavnoi psikhologii muzyki [The Thoughts on the Orthodox Psychology of Music]. In Homo musicus. Al'manakh muzykal'noi psikhologii [Homo Musicus. Music Psychology Almanac]. Moscow, 48-75.

Naiko, N.M. (2012). Opyt umiraniia v Chetvertoi simfonii Dmitriia Shostakovicha [The Experience of Dying in Dmitry Shostakovich's Symphony No. 4]. In Naiko N.M. Poznavshii tainu zvuka: stat'i o muzyke i muzykantakh [The One Who Knows the Mystery of Sound: the Articles about Music and Musicians]. Krasnoyarsk, 72-103.

Perepiska Dmitriia Shostakovicha s Veroi Dulovoi: “V kazhdoi moei note est' kaplia moei zhivoi krovi" (1934-1939) [The Correspondence between Dmitry Shostakovich and Vera Dulova: "There is a Drop of My Lifeblood in My Every Note" (1934-1939)] (2006), In Nashe nasledie [Our Heritage], 7980. Available at: www.nasledie-rus.ru/podshivka/7923.php (accessed 18 March 2010).

Rouz, S. (1995). Dusha posle smerti [Soul After Death]. St.-Petersburg, 272 p.

Rynkovskaia, N.P. (2015). Kul'tura i lichnost' v sovremennom mire [Culture and Personality in the Modern world], In Voprosy kul'turologii [The Issues of Cultural Studies], 9, 20-25.

Tynianov, Iu.N. (1993). Blok (1921). Literaturnyi Fakt [Literary Fact]. Moscow, 224-229.

Vysheslavtsev, B.T. (1994). Etika preobrazhennogo Erosa [The Ethics of the Transfigured Eros]. Moscow, $368 \mathrm{p}$.

Zhuravskii, I. (1995). Taina Tsarstviia Bozhiego [The Mystery of God's Kingdom]. Riga-St. Petersburg, 240 p. 


\section{Образ Лирического героя \\ Четвертой симфонии Д. Шостаковича \\ в свете идей христианской антропологии}

Н.М. Найко

Красноярский государственный институт искусств Россия, 660049, Красноярск, ул. Ленина, 22

Герой Четвёртой симфонии Д. Шостаковича - одного из наиболее трагических и ярко экспрессивных сочинений - является своеобразным художественным двойником автора. Интоначионными средствами композитор моделирует в музыке личность, наделённую как общечеловеческими, так и индивидуальными, присущими личности самого композитора, качествами. Применение понятий христианской антропологии позволяет осмыслить природу человека, вопломенного в образе Лирического героя Четвёртой симфонии Шостаковича. Результать интонационного анализа позволяют сделать вывод о том, что интуиции божественного происхождения человека, его духовной природы составляют смысловое ядро немногочисленных и кратких лирических эпизодов симфонии. Однако основные силы души Лирического героя искажены и ослаблены, и такая нецельность делает его уязвимым для враждебного мира. Претворение этих идей обусловливает ряд драматургических и композиционных особенностей Четвёртой симфонии. При этом характеризующие Героя музыкальные темы обнаруживают единый интонационный «стержень», неизменность которого символизирует наличие в душе Лирического героя неуничтожимого ядра и его неподвластность духовной смерти.

Ключевые слова: Симфония № 4 Д. Шостаковича, Лирический герой в музыке.

Научная специальность: 24.00.00 - культурология, 17.00.00-искусствоведение. 